\title{
研究課題別事後評価結果
}

1. 研究課題名： 超イオン伝導パスを拓く階層構造による結晶相界面デザイン

2. 研究代表者名及び主たる研究参加者名（研究機関名・職名は研究参加期間終了時点） 研究代表者

手嶋＼cjkstart勝弥（信州大学環境・エネルギー材料科学研究所＼cjkstart研究所長・教授） 主たる共同研究者

湯茼 邦夫（東北大学金属材料研究所 准教授）

西川 慶（物質・材料研究機構エネルギー・環境材料研究拠点 主任研究員）

藤田 大介（物質・材料研究機構先端材料解析研究拠点 拠点長）

3. 事後評価結果

$\bigcirc$ 評点

\section{A 優れている}

○総合評価コメント：

超高性能全固体二次電池の創成に向けて、フラックス法による固体電解質スクリーニング、稠密配向 性結晶薄膜正極材料合成法の確立、シミュレーションや理論計算等による相平衡・相転位予測など、広 範囲にわたる探索・絞り込みにより要素技術を深化させ、素材性能を高め、最終的に二次電池としての 性能評価を示寸レベルにまで到達した点は高く評価できる。

本研究課題は複数の企業との共同研究を実施し、電池材料に必要な要素技術の確立を目指したもので あり、多くの特許出願、ライセンス契約等の実績を上げている。このことは世界的に注目されている全 固体二次電池の開発において、日本の産学連携の成果と言う意味においても高く評価できる。

基礎科学の視点では、フラックス法による結晶性セラミックス材料の精密設計、反応機構の解明につ いて、専門誌への投稿から研究後半ではより評価の高い学術誌への投稿を実現し、国際的な評価も高ま りつつある。

チーム運営については、国内外を問わず多くの共同研究者と効率的に進めており、研究代表者として 高く評価している。CREST 研究期間中にコンソーシアムの形成、技術移転の組織作りを実現した点も評 価に值する。全固体二次電池材料は日本が世界に発信し得る産業的インパクトの極めて大きな対象であ り、本チームで教育・育成、昇格・異動した若手研究者の活躍も大いに期待される。 